\title{
Strategi Pendistribusian Zakat Produktif Perdagangan pada BAZNAS Kota Padang Panjang
}

\author{
Widi Nopiardo', Wahyu Nurhidayat ${ }^{2}$ \\ ${ }^{1,2}$ Institut Agama Islam Negeri Padangsidimpuan \\ 1,2 J1. Jenderal Sudirman No.137 Limo Kaum, Kabupaten Tanah Datar, Sumatera Barat \\ Email: widinopiardo@iainbatusangkar.ac.id,wahyunurhidayat@gmail.com
}

\begin{abstract}
Abstrak
Permasalahan yang dikemukakan dalam artikel ini dari tahun ke tahun yaitu dari 20162018 jumlah mustahik zakat produktif BAZNAS Kota Padang selalu mengalami meningkatan, namun pada tahun 2019 mengalami penurunan. Pendistribusian dana zakat produktif dari tahun 2016-2019 lebih dominan untuk usaha perdagangan. Kompleksitas persoalan dalam distribusi zakat produktif ini tentu membutuhkan strategi yang tepat dalam pendistribusian sehingga perlu diketahui strategi apa yang dilakukan oleh BAZNAS Kota Padang Panjang. Jenis penelitian yang penulis lakukan adalah penelitian lapangan (field research) dengan pendekatan deskriptif kualitatif. Sumber data primer dalam penelitian ini adalah Ketua BAZNAS Kota Padang Panjang, Staf Sekretariat BAZNAS Kota Padang Panjang, dan mustahik. Sumber data sekunder dalam penelitian ini adalah laporan pertanggungjawaban BAZNAS Kota Padang Panjang Tahun 2016-2019, brosur, laporan bulanan, dan dokumen terkait BAZNAS Kota Padang Panjang. Teknik pengumpulan data dalam penelitian ini adalah teknik wawancara dan dokumentasi. Hasil penelitian menunjukkan bahwa strategi pendistribusian zakat produktif perdagangan dilakukan dengan cara pengumpulan data calon mustahik, verifikasi proposal mustahik, melakukan survei kepada mustahik, membahas dan menetapkan hasil survei, pendistribusian zakat, dan monitoring usaha mustahik.
\end{abstract}

Kata Kunci: Strategi, Pendistribusian, Zakat Produktif

Abstract

The problems raised in this article from year to year, namely from 2016-2018 the number of productive zakat mustahik at BAZNAS in Padang has always increased, but in 2019 it has decreased. The distribution of productive zakat funds from 2016-2019 was more dominant for the trading business. The complexity of the problem in the distribution of productive zakat certainly requires the right strategy in distribution, so it is necessary to know what strategy is carried out by BAZNAS Padang Panjang city. The type of research that the author does is field research (field research) with a qualitative descriptive approach. The primary data sources in this study were the Head of BAZNAS Padang Panjang City, Padang Panjang City BAZNAS Secretariat Staff, and Mustahik. The secondary data sources in this research are the accountability reports of BAZNAS Padang Panjang City 2016-2019, brochures, monthly reports, and documents related to BAZNAS Padang Panjang City. Data collection techniques in this study were interview and documentation techniques. The results showed that the trade-productive zakat distribution strategy was carried out by collecting data on mustahik candidates, verifying mustahik proposals, conducting surveys of mustahik, discussing and determining survey results, distributing zakat, and monitoring mustahik businesses.

Keywords: Strategy, Distribution, Productive Zakat 


\section{PENDAHULUAN}

Zakat merupakan isim masdar dari kata zaka-yazku-zakah. Dengan demikian kata dasar zakat adalah zaka yang berarti berkah, tumbuh, bersih, baik, dan bertambah. Makna tersebut menjelaskan orang yang telah mengeluarkan zakat diharapkan hati dan jiwanya akan menjadi bersih (Fakhrruddin, 2008:13-14). Kewajiban zakat memiliki makna yang sangat fundamental. Kewajiban zakat berkaitan erat dengan aspek ketuhanan, zakat juga erat kaitannya dengan aspek sosial, ekonomi, dan kemasyarakatan.

Zakat memiliki peran sebagai distribusi dan redistribusi penghasilan dari golongan mampu kepada golongan yang kurang atau tidak mampu dan pada dasarnya merupakan pengembalian sebagian harta kekayaan orang-orang yang mampu untuk menjadi milik orang yang tidak berpunya. Zakat adalah instrumen penting dalam sektor ekonomi Islam dan mendorong kemajuan dan kemakmuran umat Islam di seluruh dunia, dengan demikian institusi zakat perlu diatur dan dikelola secara efektif dan efisien. Melalui sistem pengumpulan, pendistribusian, dan pendayagunaan yang baik, zakat dapat menjadi alternatif kestabilan krisis ekonomi dunia.

Menurut ajaran Islam, zakat sebaiknya dipungut oleh negara atau lembaga yang diberi mandat oleh negara dan atas nama pemerintah bertindak sebagai wakil fakir dan miskin. Pengelolaan di bawah otoritas yang dibentuk oleh negara akan jauh lebih efektif pelaksanaan fungsi dan dampaknya dalam membangun kesejahteraan umat yang menjadi tujuan zakat, jika dibandingkan zakat yang dikumpulkan dan didistribusikan oleh lembaga yang berjalan sendiri-sendiri yang tidak ada koordinasi. (Nopiardo, 2016:186).

Pemerintah telah membentuk Undang-Undang No. 23 Tahun 2011 tentang Pengelolaan Zakat. Undang-undang ini memuat tentang pengelolaan zakat yang terorganisir dengan baik, transparan, dan profesional dilakukan oleh amil resmi yang ditunjuk oleh pemerintah, baik Badan Amil Zakat Nasional (BAZNAS) maupun Lembaga Amil Zakat (LAZ). Zakat yang telah dikumpulkan Organisasi Pengelola Zakat (OPZ) harus segera disalurkan kepada para mustahik sesuai dengan skala prioritas yang telah ditentukan. (Nopiardo, 2016:186).

Kerangka institusional Undang-Undang No. 23 Tahun 2011, BAZNAS merupakan satusatunya pihak yang memiliki kewenangan dalam pengelolaan zakat nasional (Pasal 6) yang didirikan dari tingkat pusat sampai Kabupaten/ Kota (Pasal 15) dimana BAZNAS di setiap tingkatan dapat membentuk UPZ (Unit Pengumpulan Zakat) di setiap instansi pemerintahan sampai ke tingkat kelurahan (Pasal 16) (Wibisono, 2015:113-114). Setelah zakat terkumpul maka OPZ segera mendistribusikan zakat kepada yang berhak menerimanya. Model penunaian zakat oleh muzaki ada dua cara yaitu dapat dilakukan secara langsung kepada mustahik atau lewat lembaga zakat yang nantinya akan disalurkan kepada mustahik. 
Distribusi zakat secara langsung atau tidak melalui amil terkadang hanya berputar pada daerah tertentu dan tidak maksimal dalam peningkatan ekonomi mustahik. Berbeda halnya jika penunaian zakat melalui OPZ yang profesional sehingga dalam penyalurannya cenderung lebih merata dan berimplikasi pada peningkatan kesejahteraan mustahik (Syahriza, 2019:143). Penyaluran dana zakat oleh OPZ terbagi menjadi penyaluran dana zakat konsumtif dan produktif. Penyaluran dana zakat konsumtif terdiri dari konsumtif tradisional dan konsumtif kreatif.

Konsumtif tradisional yaitu zakat dibagikan kepada mustahik secara langsung untuk kebutuhan konsumsi sehari-hari, seperti pembagian zakat fitrah berupa beras dan uang kepada fakir miskin setiap Idul Fitri atau pembagian zakat mal secara langsung oleh para muzakki kepada mustahik yang sangat membutuhkan karena ketiadaan pangan atau karena mengalami musibah. Konsumtif kreatif, yaitu zakat yang diwujudkan dalam bentuk barang konsumtif dan digunakan untuk membantu orang miskin dalam mengatasi permasalahan sosial dan ekonomi yang dihadapinya.

Penyaluran dana zakat produktif terdiri dari zakat produktif konvensional dan zakat produktif kreatif. Produktif konvensional merupakan zakat yang diberikan dalam bentuk barang-barang produktif, dimana dengan menggunakan barang-barang tersebut para mustahik dapat menciptakan suatu usaha, seperti pemberian bantuan ternak kambing, sapi perahan atau untuk membajak sawah, alat pertukangan, mesin jahit, dan sebagainya. Produktif kreatif merupakan zakat yang diwujudkan dalam bentuk pemberian modal bergulir, baik untuk permodalan proyek sosial, seperti membangun sekolah, sarana kesehatan, atau tempat ibadah maupun sebagai modal usaha untuk membantu pengembangan usaha para pedagang atau pengusaha kecil (Fakhrruddin, 2008:314-315).

Pengertian harta zakat secara produktif artinya harta zakat yang dikumpulkan dari muzakki tidak habis dibagikan sesaat begitu saja untuk memenuhi kebutuhan yang bersifat konsumtif, melainkan harta zakat itu sebagian ada yang diarahkan pendayagunaannya kepada yang bersifat produktif. Dalam arti harta zakat itu didayagunakan (dikelola), dikembangkan sedemikian rupa sehingga bisa mendatangkan manfaat (hasil) yang akan digunakan dalam memenuhi kebutuhan orang yang tidak mampu (terutama fakir miskin) tersebut dalam jangka panjang. Secara bertahap, pada suatu saat nanti mustahik tidak lagi masuk kepada kelompok mustahik zakat, melainkan lama-kelamaan menjadi muzakki Rafi', 2011:132).

Pendayagunaan harta zakat secara produktif, edukatif, dan ekonomis untuk konteks saat ini sangat diperlukan. Pendayagunaan harta zakat secara produktif tersebut yang diterima oleh mustahik tidak bisa habis begitu saja, akan tetapi bisa dikembangkan sesuai dengan kehendak dan tujuan dari syari'at zakat, yaitu menghilangkan kemiskinan serta mensejahterakan bagi kaum duafa, dengan harapan secara bertahap mereka tidak selamanya menjadi mustahik melainkan menjadi muzakki. Harta zakat akan semakin berkembang

JISFIM: Journal of Islamic Social Finance Management, Volume 2, No 1 Tahun 2021 http://jurnal.iain-padangsidimpuan.ac.id/index.php/JISFIM 
sehingga akan menjadi jumlah yang cukup banyak. Pengembangan tersebut tetap diarahkan untuk membantu menyantuni mustahik zakat menuju kemandirian mereka (Rafi', 2011:142).

Pendayagunaan zakat yang dikelola oleh Badan Amil Zakat Nasional tidak hanya terbatas pada kegiatan-kegiatan tertentu saja yang berdasarkan pada orientasi konvensional, tetapi dapat pula dimanfaatkan untuk kegiatan-kegiatan ekonomi umat, seperti dalam program pengentasan kemiskinan dan pengangguran dengan memberikan zakat produktif kepada mereka yang memerlukan sebagai modal usaha. Hal ini pemberian zakat kepada fakir miskin disertai dengan usaha memperbaiki sikap mental dan sikap kehidupannya. Mustahik pun tidak lepas begitu saja setelah menerima zakat, tetapi dibimbing agar berhasil dalam kegiatan usahanya (Hidajat, 2017:67-68).

Cara pendistribusian yang tepat guna, efektif manfaatnya dengan sistem yang serba guna dan produktif, sesuai dengan pesan syariat dan peran serta fungsi sosial ekonomi zakat. Zakat produktif adalah model pendistribusian zakat yang dapat membuat para mustahik menghasilkan sesuatu secara terus menerus, dengan harta zakat yang diberikan kepada mustahik tidak dihabiskan atau dikosumsi tapi dikembangkan dan digunakan untuk membantu usaha mereka, sehingga dengan usaha tersebut mustahik dapat memenuhi kebutuhan hidup secara terus menerus, bahkan berubah status dari mustahik menjadi muzakki (Thoriquddin, 2015:29-30)

BAZNAS Kota Padang Panjang merupakan sebuah lembaga yang dibentuk pemerintah yang bertugas untuk mengelola zakat. BAZNAS Kota Padang Panjang memiliki program pendistribusian dana zakat produktif. Program pendistribusian dana zakat produktif pada BAZNAS Kota Padang Panjang adalah program Padang Panjang Makmur (Modal Usaha). Pendistribusian zakat produktif pada BAZNAS Kota Padang Panjang lebih dominan diarahkan pada bantuan modal untuk usaha perdagangan (Wetrita Yetni, wawancara, 12 April 2019). Data awal yang peneliti peroleh dari program pendistribusian dana zakat produktif pada BAZNAS Kota Padang Panjang adalah sebagai berikut:

\section{Tabel 1.}

Data Jumlah Penerima Dana Zakat Produktif BAZNAS Kota Padang Panjang

\begin{tabular}{lllllll}
\hline $\begin{array}{l}\text { Program } \\
\text { Produktif }\end{array}$ & Pendistribusian & Dana & Zakat & \multicolumn{3}{l}{ Jumlah Penerima Dana Zakat Produktif } \\
\cline { 3 - 6 } & & & $\mathbf{2 0 1 6}$ & $\mathbf{2 0 1 7}$ & $\mathbf{2 0 1 8}$ & $\mathbf{2 0 1 9}$ \\
\hline $\begin{array}{l}\text { Program Padang } \\
\text { (Modal Usaha) }\end{array}$ & Panjang & Makmur & 382 & 452 & 541 & 428 \\
\hline \begin{tabular}{l} 
Jumlah \\
\cline { 3 - 6 }
\end{tabular} & & $\mathbf{3 8 2}$ & $\mathbf{4 5 2}$ & $\mathbf{5 4 1}$ & $\mathbf{4 2 8}$
\end{tabular}

Sumber: Diolah dari Laporan Pertanggungjawaban Pimpinan BAZNAS Kota Padang Panjang Tahun 2016-2019 
Sementara itu, jenis usaha penerima dana zakat produktif BAZNAS di Kota Padang Panjang dengan total sebanyak 428 pada tahun 2019 menurun dari tahun 2018. Selengkapnya dapat dilihat pada Tabel 2.

Tabel 2.

Data Jenis Usaha Penerima Dana Zakat Produktif BAZNAS Kota Padang Panjang

\begin{tabular}{lllcccc}
\hline \multirow{2}{*}{$\begin{array}{l}\text { Jenis Usaha } \\
\text { Produktif }\end{array}$} & Penerima & Dana & Zakat & \multicolumn{3}{c}{ Jumlah Penerima Dana Zakat Produktif } \\
\cline { 3 - 6 } & & $\mathbf{2 0 1 6}$ & $\mathbf{2 0 1 7}$ & $\mathbf{2 0 1 8}$ & $\mathbf{2 0 1 9}$ \\
\hline $\mathbf{1}$ & Usaha Perdagangan & 338 & 376 & 459 & 327 \\
\hline $\mathbf{2}$ & Usaha Jasa & 32 & 61 & 54 & 66 \\
\hline $\mathbf{3}$ & Usaha Pertanian & 6 & 9 & 11 & 26 \\
\hline $\mathbf{4}$ & Usaha Peternakan & 6 & 6 & 17 & 9 \\
\hline Jumlah & $\mathbf{3 8 2}$ & $\mathbf{4 5 2}$ & $\mathbf{5 4 1}$ & $\mathbf{4 2 8}$ \\
\hline
\end{tabular}

Sumber: Diolah dari Laporan Pertanggungjawaban Pimpinan BAZNAS Kota Padang Panjang Data Rekap Tahun 2016-2019

Data di atas menjelaskan bahwa pendistribusian dana zakat produktif oleh BAZNAS Kota Padang Panjang dari tahun 2016-2018 mengalami peningkatan sedangkan pada tahun 2019 mengalami penurunan. Tabel 1.2 menunjukkan bahwa pendistribusian dana zakat produktif dari tahun 2016-2019 lebih dominan untuk usaha perdagangan. Mengingat banyaknya jumlah mustahik sesuai data pada tabel di atas, adanya kenaikan jumlah mustahik dari tahun ke tahun yaitu dari tahun 2016 s.d. 2018, tentu dibutuhkan strategi pendistribusian agar program pendistribusian terlaksana dengan baik. Berdasarkan latar belakang tersebut maka penulis tertarik untuk melakukan penelitian yang berjudul "Strategi Pendistribusian Zakat Produktif Perdagangan pada BAZNAS Kota Padang Panjang”.

\section{KAJIAN TEORITIS}

\section{Organisasi Pengelola Zakat}

Pemerintah telah membentuk Undang-Undang No. 23 Tahun 2011 tentang Pengelolaan Zakat. Undang-undang ini memuat tentang pengelolaan zakat yang terorganisir dengan baik, transparan, dan profesional dilakukan oleh amil resmi yang ditunjuk oleh pemerintah, baik Badan Amil Zakat Nasional (BAZNAS) maupun Lembaga Amil Zakat (LAZ). Zakat yang telah dikumpulkan oleh Organisasi Pengelola Zakat (OPZ) harus segera disalurkan kepada para mustahik sesuai dengan skala prioritas yang telah ditentukan (Nopiardo, 2016:186).

Sekarang ini mulai tumbuh kesadaran masyarakat untuk berzakat. Hal ini ditandai dengan banyaknya lembaga amil zakat maupun badan amil zakat yang bermunculan. Namun begitu, kesadaran berzakat maupun dana zakat belum sepenuhnya menyentuh seluruh lapisan 
masyarakat. Kita bisa lihat dari sekian banyak instansi pemerintah, berapa yang mempunyai Unit Pengumpul Zakat (UPZ), dan dana yang terkumpul belum bisa menjangkau seluruh mustahik yang ada (Thoriquddin, 2015:33). Menurut Thoriquddin (2015:33-34) setidaknya ada tiga strategi yang dapat diterapkan oleh instansi pengelola zakat yaitu sebagai berikut: (a) Pembentukan Unit Pengumpulan Zakat (UPZ). Setiap badan amil zakat dapat membuka UPZ di berbagai tempat sesuai dengan tingkatannya, baik nasional, provinsi, dan seterusnya; (b) Pembukaan counter penerimaan zakat. Pembukaan counter atau loket di kantor atau lembaga sekretariat lembaga yang bersangkutan. Counter harus dibuat representatif layaknya loket lembaga keuangan profesional yang dilengkapi ruang tunggu, alat tulis, penghitung seperlunya, brankas, ditunggu dan dilayani oleh tenaga-tenaga professional; (c) Pembukaan rekening bank. Pembukaan rekening bank hendaknya dipisah antara satu rekening dengan yang lainnya, semisal rekening zakat, infak, sedekah, dan wakaf sehingga memudahkan bagi muzaki menyetor dana zakat, infak, sedekah dan memudahkan pengelola untuk mendistribusikannya.

\section{Pendistribusian Zakat Produktif}

Pendistribusian zakat sangat diperlukan partisipasi banyak pihak. Semua pihak yang berwenang jika turut serta untuk mensukseskan pengelolaan zakat yang baik dan optimal maka program pengentasan kemiskinan insya Allah bisa diwujudkan. Pengentasan kemiskinan melalui zakat juga berarti mengurangi jumlah mustahik dan menghasilkan para muzaki yang baru. Oleh karena itu pendistribusian zakat konsumtif harus ditinjau ulang kembali, dan hanya diberikan setelah melalui kajian yang matang untuk memenuhi kebutuhan dasar mustahik. Pendistribusian zakat produktif selalu menjadi perhatian dalam rangka peningkatan perekonomian mustahik. Zakat produktif adalah pemberian zakat yang dapat membuat para penerimanya menghasilkan sesuatu secara terus menerus, dengan harta zakat yang telah diterimanya (Nopiardo, 2016:187).

Kata produktif secara bahasa berasal dari bahasa Inggris yaitu "productive" yang berarti banyak menghasilkan, memberikan banyak hasil, banyak menghasilkan barang-barang berharga, yang mempunyai hasil baik. "Productivity" berarti daya produksi. Secara umum produktif (productive) berarti banyak menghasilkan karya atau barang. Produktif juga berarti "banyak menghasilkan, memberikan banyak hasil." Penggabungan kata zakat dan produktif mempunyai arti yaitu zakat yang dalam pendistribusiannya dilakukan dengan cara produktif lawan dari kata konsumtif, atau dengan kata lain penamaan zakat produktif ini diambil dari tujuan pendistribusian zakat tersebut yaitu "untuk diproduktifkan", bukan diambil dari klasifikasi zakat seperti zakat mal atau zakat fitrah, dan juga bukan diambil dari jenis-jenis harta yang wajib dikeluarkan zakatnya seperti zakat binatang ternak, zakat pertanian, dan lain sebagainya.

JISFIM: Journal of Islamic Social Finance Management, Volume 2, No 1 Tahun 2021 http://jurnal.iain-padangsidimpuan.ac.id/index.php/JISFIM 
Zakat produktif adalah pemberian zakat yang dapat membuat para penerimanya menghasilkan sesuatu secara terus menerus dengan harta zakat yang telah diterimanya. Harta atau dana zakat yang diberikan kepada mustahik tidak dihabiskan, tetapi dikembangkan dan digunakan untuk membantu usaha mereka, sehingga dengan usaha tersebut mereka dapat memenuhi kebutuhan hidup secara terus menerus. Harta zakat yang didayagunakan dan dikembangkan sedemikian rupa dapat mendatangkan manfaat yang akan digunakan dalam memenuhi kebutuhan mustahik tersebut dalam jangka panjang, dengan harapan secara bertahap, pada suatu saat tidak lagi masuk dalam kelompok mustahik zakat (Syahriza, 2019:144-145).

Cara pendistribusian yang tepat guna, efektif manfaatnya dengan sistem yang serba guna dan produktif, sesuai dengan pesan syariat dan peran serta fungsi sosial ekonomi zakat. Zakat produktif adalah model pendistribusian zakat yang dapat membuat para mustahik menghasilkan sesuatu secara terus menerus, dengan harta zakat yang diberikan kepada mustahik tidak dihabiskan atau dikosumsi tapi dikembangkan dan digunakan untuk membantu usaha mereka, sehingga dengan usaha tersebut mustahik dapat memenuhi kebutuhan hidup secara terus menerus, bahkan berubah status dari mustahik menjadi muzakki (Thoriquddin, 2015:29-30).

Salah satu fungsi zakat adalah fungsi sosial, yaitu sarana bersosialisasi antara orang kaya dan orang miskin, agar dana zakat yang disalurkan dapat berdaya guna dan berhasil guna, maka dalam pemanfaatannya harus selektif. Pendistribusian dana zakat setidaknya memiliki dua model distribusi yaitu konsumtif dan produktif. Kedua model di atas masing-masing terbagi menjadi dua yaitu konsumtif tradisional dan konsumtif kreatif dan produktif konvensional serta produktif kreatif (Thoriquddin, 2015:34-35).

Pendayagunaan zakat yang dikelola oleh Badan Amil Zakat tidak hanya terbatas pada kegiatan-kegiatan tertentu saja yang berdasarkan pada orientasi konvensional, tetapi dapat pula dimanfaatkan untuk kegiatan-kegiatan ekonomi umat, seperti program pengentasan kemiskinan dan pengangguran dengan memberikan zakat produktif kepada mereka yang memerlukan sebagai modal usaha. Dalam hal ini pemberian zakat kepada fakir miskin disertai dengan usaha memeperbaiki sikap mental dan sikap kehidupannya. Mustahik pun tidak lepas begitu saja setelah menerima zakat, tetapi kemudian dibimbing agar berhasil dalam kegiatan usahanya (Hidajat, 2017:67-68).

\section{METODE PENELITIAN}

Jenis penelitian dalam penelitian ini adalah dengan menggunakan jenis penelitian lapangan (field research) dengan pendekatan deskriptif kualitatif. Penelitian ini berlokasi di BAZNAS Kota Padang Panjang yang terletak di Jl. Mr. Assa'at No. 14 (Terminal KANTIN) Kota Padang Panjang Sumatera Barat yang dimulai dari bulan Januari s.d. Juni 2020. Sumber data 
dalam sebuah penelitian terbagi menjadi dua yaitu: Sumber data primer berupa informan yaitu Ketua BAZNAS Kota Padang Panjang, staf sekretariat BAZNAS Kota Padang Panjang, penerima dana zakat produktif untuk usaha perdagangan dari BAZNAS Kota Padang Panjang tahun 2016-2019. Sedangkan sumber Data Sekunder berupa laporan pertanggungjawaban pimpinan BAZNAS Padang Panjang pada tahun 2016-2019, brosur, laporan bulanan, dan dokumen terkait BAZNAS Kota Padang Panjang.

Teknik pengumpulan data dilakukan dengan 2 cara yaitu: Wawancara, alam penelitian ini, peneliti melakukan wawancara dengan Ketua BAZNAS Kota Padang Panjang yaitu Bapak Drs. H. Aswir Rasydin Dt. Panjang, Staf Sekretariat BAZNAS Kota Padang Panjang yaitu Ibu Wetrita Yetni yang berkaitan dengan penyaluran dana zakat produktif pada BAZNAS Kota Padang Panjang, dan beberapa mustahik teknik snawball sampling. Kedua, dokumentasi dimana pengumpulan data dalam penelitian ini juga menggunakan dengan teknik dokumentasi yaitu melalui laporan pertanggungjawaban pimpinan BAZNAS Kota Padang Panjang pada tahun 2016-2019, brosur, laporan bulanan, dan dokumen terkait BAZNAS Kota Padang Panjang.

Setelah data terkumpul, peneliti akan mengolahnya dengan mengadakan analisis dengan analisis model Miles dan Huberman terhadap data yang terkumpul dengan tahap reduksi data, tahap penyajian data, dan tahap penarikan kesimpulan dan verifikasi data. Tahap tersebut terdiri dari: (1) Tahap Reduksi Data dimana melakukan reduksi merupakan penyederhanaan terhadap klasifikasi data dan kemudian mengelompokkan masing-masing data. Dalam hal ini penulis lebih memfokuskan pada penyaluran dana zakat produktif pada BAZNAS Kota Padang Panjang; (2) Tahap Penyajian Data dimana pada langkah ini peneliti berusaha menyusun data yang relevan sehingga menjadi informasi yang dapat disimpulkan, dimana prosesnya dapat dilakukan dengan cara menampilkan data, membuat hubungan antar fenomena untuk memaknai apa yang sebenarnya terjadi dan apa yang perlu ditindaklanjuti untuk mencapai tujuan penelitian dan (3) Tahap Penarikan Kesimpulan dimana pada tahap ini peneliti malakukan penarikan kesimpulan. Dalam penelitian kualitatif ini kesimpulan dapat menjawab rumusan masalah yang telah dirumuskan sejak awal (Ilyas, 2016:94).

\section{HASIL DAN PEMBAHASAN}

Strategi pendistribusian zakat produktif perdagangan pada BAZNAS Kota Padang Panjang adalah sebagai berikut:

1. Mengumpulkan Data Calon Mustahik

BAZNAS Kota Padang Panjang bekerjasama dengan kelurahan-kelurahan yang ada di Kota Padang Panjang untuk menyampaikan kepada setiap RT, agar masyarakat yang ingin dibantu mengajukan proposal bantuan kepada pihak BAZNAS Kota Padang Panjang. Mustahik yang membutuhkan modal atau bantuan 
dari BAZNAS Kota Padang Panjang harus mengajukan permohonan sesuai dengan persyaratan dan rencana penggunaannya kepada BAZNAS Kota Padang Panjang dengan melampirkan syarat sebagai berikut:

a. Surat Keterangan Miskin dari kelurahan.

b. Fotokopi Kartu Tanda Penduduk (KTP).

c. Fotokopi Kartu Keluarga (KK).

d. Rekomendasi dari pengurus masjid/ mushalla.

e. Rancangan Anggaran Belanja (RAB) (Dokumen BAZNAS Kota Padang Panjang, 2019:13).

2. Memverifikasi Proposal Mustahik

Dalam melakukan verifikasi proposal mustahik zakat produktif perdagangan, pihak BAZNAS Kota Padang Panjang melakukan pemeriksaan terhadap data calon mustahik yang mengajukan proposal permohonan bantuan zakat produktif. Pihak BAZNAS Kota Padang Panjang akan menghubungi calon mustahik apabila data yang diberikan kepada BAZNAS Kota Padang Panjang belum lengkap. Jika data sudah dilengkapi, maka pihak BAZNAS Kota Padang Panjang melanjutkan proses permohonan calon mustahik ke tahap selanjutnya (H. Aswir Rasydin Dt. Panjang, wawancara, o3 Februari 2020).

3. Melakukan Survei Mustahik

BAZNAS Kota Padang Panjang membentuk tim survei yang terdiri dari 2 (dua) orang, dimana 1 (satu) orang bertugas di Kecamatan Padang Panjang Barat dan 1 (satu) orang bertugas di Kecamatan Padang Panjang Timur. Tim survey akan melakukan survey sebelum bulan Maret untuk periode pertama, sebelum bulan Juni untuk periode kedua, sebelum bulan September untuk periode ketiga, dan sebelum bulan Desember untuk periode keempat. Tim survey harus menyelesaikan survey sebelum bulan tersebut, karena pada bulan Maret, Juni, September, dan Desember pihak BAZNAS Kota Padang Panjang akan mendistribusikan zakat produktif perdagangan pada mustahik.

Pihak BAZNAS Kota Padang Panjang melakukan survei lapangan ke alamat calon mustahik untuk mengetahui kondisi usaha perdagangan agar pihak BAZNAS Kota Padang Panjang mengetahui layak atau tidaknya calon mustahik untuk menerima modal atau bantuan. Pihak BAZNAS Kota Padang Panjang akan menentukan layak atau tidaknya calon mustahik untuk menerima modal atau bantuan dengan kondisi memiliki usaha namun kurang berkembang, kondisi memiliki peluang dan adanya niat untuk berusaha, kondisi kekurangan modal untuk membuka usaha, dan kondisi pernah berusaha namun mengalami kegagalan. Kriteria tersebut ditentukan oleh pihak BAZNAS Kota Padang Panjang http://jurnal.iain-padangsidimpuan.ac.id/index.php/JISFIM 
melalui hasil survey lapangan. Mustahik dengan kondisi tersebut dianggap layak untuk menerima modal atau bantuan untuk usaha perdagangan oleh tim survei lapangan (H. Aswir Rasydin Dt. Panjang, wawancara, o3 Februari 2020).

4. Membahas dan Menetapkan Hasil Survei

Membahas dan menetapkan hasil survei untuk menentukan mustahik yang layak dibantu zakat produktif Perdagangan pada BAZNAS Kota Padang Panjang. Hasil survey akan didiskusikan bersama Ketua BAZNAS Kota Padang Panjang beserta Wakil Ketua I, II, III, dan IV BAZNAS Kota Padang Panjang. Pada rapat yang dilakukan tim survei dengan ketua dan seluruh wakil ketua (unsur pimpinan) akan ditentukan berapa jumlah calon mustahik yang akan menerima dana zakat produktif perdagangan dan juga ditentukan berapa nominal yang akan diperoleh oleh mustahik (H. Aswir Rasydin Dt. Panjang, wawancara, o3 Februari 2020).

Penetapan jumlah mustahik zakat produktif perdagangan pada BAZNAS Kota Padang Panjang secara umum pihak BAZNAS Kota Padang Panjang tidak menentukan patokan jumlah mustahik yang dibantu setiap tahunnya, melainkan dari mustahik yang dinyatakan layak dan pantas untuk dibantu berdasarkan hasil survey. Dari calon mustahik yang mengajukan proposal permohonan bantuan untuk usaha perdagangan disurvey terlebih dahulu untuk menentukan kelayakan calon mustahik untuk dibantu. Setelah dinyatakan layak barulah diberikan bantuan dana zakat produktif untuk usaha perdagangan. Pada BAZNAS Kota Padang Panjang yang dominan mengajukan proposal permohonan bantuan yaitu untuk usaha perdagangan, karena masyarakat Kota Padang Panjang dominan memiliki usaha yang bergerak di bidang perdagangan (H. Aswir Rasydin Dt. Panjang, wawancara, 03 Februari 2020).

5. Mendistribusian Zakat

Pendistribusian zakat produktif perdagangan pada BAZNAS Kota Padang Panjang dilakukan dengan cara mengumpulkan para mustahik yang telah dinilai layak untuk mendapatkan bantuan. Mustahik biasanya dikumpulkan di masjid untuk memperoleh arahan dan bimbingan mengenai pengelolaan usaha agar maju dan berkembang. Mustahik penerima zakat produktif perdagangan diarahkan membeli kebutuhan dagangnya di Toko Prima Rasa dan Toko Bayu, kemudian pihak BAZNAS Kota Padang Panjang akan membayar kebutuhan dagang yang telah dibeli di Toko Prima Rasa dan Toko Bayu. (H. Aswir Rasydin Dt. Panjang, wawancara, 03 Februari 2020)

Pihak BAZNAS Kota Padang Panjang akan memberikan bantuan kepada calon mustahik dalam bentuk tunai dan non tunai. Pemberian bantuan tersebut tergantung dari usaha yang dijalankan oleh mustahik. Pada umumnya bantuan 
dalam bentuk uang tunai diberikan kepada mustahik yang menjalankan usaha P\&D, sementara bantuan dalam bentuk tunai diberikan kepada mustahik yang menjalankan usaha seperti sarapan pagi, jualan sate, jualan gorengan, dan lainlain. (H. Aswir Rasydin Dt. Panjang, wawancara, o3 Februari 2020)

Calon mustahik penerima zakat produktif perdagangan membenarkan bahwa sebelum mereka memperoleh bantuan modal, tim survey BAZNAS Kota Padang Panjang datang ke alamat calon mustahik untuk memeriksa terlebih dahulu keadaan usaha yang dijalankan calon mustahik. Selain memeriksa keadaan usaha calon mustahik, tim survey juga memeriksa rencana penggunaan yang dilampirkan saat mengajukan proposal bantuan kepada BAZNAS Kota Padang Panjang (Meliza Eka Putri, Asnidar, dan Gusnita, wawancara, 17 Februari 2020).

\section{Monitoring Usaha Mustahik}

Pihak BAZNAS Kota Padang Panjang akan membentuk tim untuk melakukan kegiatan monitoring terhadap usaha mustahik. Tim survey akan dibagi menjadi dua yaitu tim monitoring untuk Padang Panjang Barat dan tim survey untuk Padang Panjang Timur. Kedua tim yang dibentuk oleh pihak BAZNAS Kota Padang Panjang akan memoitoring usaha perdagangan mustahik setiap hari Rabu. Tim monitoring memberikan arahan dan masukan kepada mustahik saat monitoring. Hal ini bertujuan agar mustahik dapat mengelola dan menjalankan usahanya dengan baik. BAZNAS Kota Padang Panjang dapat mendampingi mustahik dalam menjalankan usaha dan memberikan solusi kepada mustahik yang memiliki kendala dalam menjalankan usaha perdagangannya (H. Aswir Rasydin Dt. Panjang, wawancara, 03 Februari 2020).

Pihak BAZNAS Kota Padang Panjang langsung mendatangi alamat usaha mustahik untuk memonitoring dan mengevaluasi usaha mustahik. Pihak BAZNAS Kota Padang Panjang juga memantau keadaan dari usaha yang dijalankan oleh mustahik, serta memberikan masukan, arahan, dan solusi jika mustahik mengalami kendala dalam menjalankan usahanya (Masniar dan Usman Gule, wawancara, 17 Februari 2020).

\section{KESIMPULAN}

Pada Berdasarkan penelitian tentang strategi pendistribusian zakat produktif perdagangan pada BAZNAS Kota Padang Panjang, dapat ditarik kesimpulan bahwa strategi pendistribusian zakat produktif dilakukan dengan terstruktur meliputi sebagai berikut: mengumpulkan data calon mustahik, memverifikasi proposal mustahik, melakukan survei mustahik, membahas dan menetapkan hasil survei, mendistribusikan zakat, monitoring usaha mustahik. 


\section{DAFTAR PUSTAKA}

Aswir Rasydin Dt. Panjang, wawancara, o3 Februari 2020.

Badan Amil Zakat Nasional Kota Padang Panjang. 2016. Laporan Pertanggungjawaban Pimpinan BAZNAS Kota Padang Panjang tentang Pengelolaan Zakat Tahun 2016. Padang Panjang: BAZNAS Kota Padang Panjang.

Badan Amil Zakat Nasional Kota Padang Panjang. 2017. Laporan Pertanggungjawaban Pimpinan BAZNAS Kota Padang Panjang tentang Pengelolaan Zakat Tahun 2017. Padang Panjang: BAZNAS Kota Padang Panjang.

Badan Amil Zakat Nasional Kota Padang Panjang. 2018. Laporan Pertanggungjawaban Pimpinan BAZNAS Kota Padang Panjang tentang Pengelolaan Zakat Tahun 2018. Padang Panjang: BAZNAS Kota Padang Panjang.

Badan Amil Zakat Nasional Kota Padang Panjang. 2019. Laporan Pertanggungjawaban Pimpinan BAZNAS Kota Padang Panjang tentang Pengelolaan Zakat Tahun 2019. Padang Panjang: BAZNAS Kota Padang Panjang.

Fakhrruddin. 2008. Fiqh dan Manajemen Zakat Di Indonesia. Malang: UIN Malang Press.

Hidajat, R. 2017. Penerapan Manajemen Zakat Produktif dalam Meningkatkan Ekonomi Umat di PKPU (Pos Keadilan Peduli Umat) Kota Makassar. Jurnal Studi Agama XVII(1):67-68.

Ilyas. 2016. Pendidikan Karakter melalui Homeschooling. Jurnal of Nonformal Education 2(1):94.

Masniar dan Usman Gule, wawancara, 17 Februari 2020.

Meliza Eka Putri, et.al., wawancara, 17 Februari 2020.

Nopiardo, W. 2016. Mekanisme Pengelolaan Zakat Produktif pada Badan Amil Zakat Nasional Tanah Datar. JEBI (Jurnal Ekonomi dan Bisnis Islam) 1(2):186-187.

Rafi', M. 2011. Potensi Zakat (Dari Konsumtif-Karikatif ke Produktif-Berdayaguna). Yogyakarta: Citra Pustaka Yogyakarta.

Syahriza, M. dkk. 2019. Analisis Efektivitas Distribusi Zakat Produktif Dalam Meningkatkan Kesejahteraan Mustahik (Studi Kantor Cabang Rumah Zakat Sumatera Utara). Jurnal At-Tawassuth 4(1):138-145

Thoriquddin, M. 2015. Pengelolaan Zakat Produktif Perspektif Maqasid Al-Syarïah Ibnu 'Asyur. Malang: UIN Maliki Press.

Wibisono, Y. 2015. Mengelola Zakat Indonesia. Jakarta: Kencana. 